\title{
Performance Appraisal Decision and Cognitive Processing Model: A Case of Novice and Expert Raters in the Educational Organization
}

\author{
RUSLI AHMAD \\ Faculty of Cognitive Sciences and Human Development \\ Universiti Malaysia Sarawak \\ AZMAN ISMAIL \\ Universiti Pertahanan Nasional Malaysia \\ MOHAMAD MADI ABDULLAH \\ College of Business Management and Accounting \\ Universiti Tenaga Nasional
}

\begin{abstract}
This paper explores rater (novice and expert) understanding of the decision-making process in the performance appraisal system (PAS) by looking at the cognitive processing model (CPM). Interviews were conducted using a semi-structured cognitive mapping protocol involving 22 Malaysian public school administrators and were analysed using key word analysis. The decision explorer software was used to map the thinking activities involved in the rater decision-making process. The findings revealed that raters recognised the CPM steps in their performance appraisal practice. The study also identified the differences between individual novice and expert raters' CPM in terms of concept and complexity, and also an attempt was made to compare the CPM practised by the raters with that suggested in the research framework. Every cognitive map by the raters has its own uniqueness and represents raters capability to process relevant information involved during the performance appraisal decision-making process. This paper contributes to the body of knowledge by offering a new perspective to understanding performance rating by looking at the steps involved in CPM. The research also offered some insights to policy makers, practitioners, researchers, and scholars in order to undertake further research and analysis using the steps in the CPM in a new issue, context, and environment.
\end{abstract}

Keywords: Performance appraisal; cognitive process model; decision making; public service.

\begin{abstract}
ABSTRAK
Artikel ini melaporkan kajian yang bertujuan untuk meneroka pemahaman pegawai penilai prestasi berkategori novis dan pakar terhadap pembuatan keputusan berkaitan penilaian prestasi, dengan melihat aspek model pemprosesan kognitif. Temu bual menggunakan teknik protokol peta minda separa struktur telah dijalankan terhadap 22 orang pentadbir sekolah awam di Malaysia dan data telah dianalisis menggunakan kaedah analisa kata kunci. Perisian komputer 'Decision Explorer' telah digunakan untuk membantu membina peta minda bagi menunjukkan proses pemikiran atau aktiviti berfikir dalam proses membuat keputusan berkaitan prestasi pekerja. Dapatan kajian menunjukkan langkah-langkah yang terlibat di dalam model pemprosesan kognitif adalah diikuti atau dapat dikesan dalam kalangan responden yang terlibat di dalam proses pembuatan keputusan berkaitan prestasi pekerja. Dapatan kajian juga menunjukkan terdapat perbezaan peta model pemprosesan kognitif di antara kumpulan penilai novis dan penilai kumpulan pakar. Perbezaan tersebut dari segi konsep dan kompleksiti
\end{abstract}


proses. Kajian juga dijalankan untuk membuat perbandingan antara model pemprosesan kognitifyang diikuti oleh responden kajian dengan yang terdapat di dalam literatur. Didapati setiap peta kognitif berkaitan perkara yang dikaji mempunyai keunikan tersendiri antara satu informan dengan informan yang lain dan ini menggambarkan kemampuan individu informan memproses maklumat berkaitan di dalam pembuatan keputusan berkaitan dengan prestasi pekerja. Artikel ini menyumbangkan kepada ilmu berkaitan bidang yang dikaji dengan mengemukakan perspektif baru untuk memahami proses pembuatan keputusan berkaitan dengan prestasi pekerja iaitu, dengan melihatnya dari sudut model pemprosesan kognitif. Kajian ini juga mengemukakan beberapa sumbangan untuk kumpulan pembuat dasar, pengamal, penyelidik dan sarjana. Penyelidikan tentang model pemprosesan kognitif mungkin boleh dijalankan terhadap isu lain, juga di dalam konteks dan persekitaran yang berbeza.

Kata kunci: Penilaian prestasi; model pemprosesan kognitif; pembuatan keputusan; sektor awam.

\section{INTRODUCTION}

Contemporary strategic human resource management study looks at employees as the most important asset in the organisation. Employees become a strategic tool for an organisation to survive in competitive and turbulent situations (Argyris, 1994; Ahmad \& Spicer, 2000). Nowadays the word human capital is being used widely and represents the significant contribution of human role or power in day to day management activities. Drucker (1994) stated that employees could determine the organisation's survival. Many factors can affect the commitment and motivation of workers in the workplace. One of the important aspects is employees' appraisal. Employees' pay and reward system must be carefully planned and implemented. It is hoped that by using a systematic, valid, and reliable performance appraisal system, employees will feel motivated and can perform at higher levels of performance to fulfil their own needs and to strive toward the achievement of the organisational vision. Studies had shown that employee performance appraisal is a subject of great interest in most organisations (Armstrong, 1998; Bratton \& Gold, 1999) because of the effects and consequences that the appraisal decision can have on the income of workers. Several human resource scholars have suggested the importance of workers' pay and salary (Perry, 1995; Millward, Bryson, \& Forth, 2000), although they argued that monetary rewards are not the ultimate goal. However, Furnham (1994) claimed that money could influence the workers' motivation, and also act as an incentive for workers to be loyal to their organisation. Due to this, it is important for organisations to take care of their workers' income and welfare. This paper discusses research on performance appraisal system (PAS) in the Malaysian Public Service (MPS) by looking at the cognitive processing model (CPM) of raters. It offers an understanding and explanation of the role of CPM as a new perspective in the decision-making process. In MPS, performance appraisal decisions are of great interest to employees because they can affect their monthly salary and their commitment in the work place (Abdul Hamid, 1996; 1999). PAS can also be seen as influencing job satisfaction and motivation of workers. The first part of this paper looks at the practice of appraisal process in general, and specifically in MPS, followed by a discussion on CPM. Research questions and research design in this study are also discussed. Finally, research findings are detailed, and the paper ends by discussing conclusions and drawing implications for the CPM and appraisal decisionmaking process.

\section{PERFORMANCE APPRAISAL PROCESS}

Performance appraisal can be defined as a periodic evaluation of the output of an individual measured against certain expectations (Yong, 1998). Performance appraisal is the process of observing and evaluating staff member's performance at the work place in relation to preset standards. Classical views of performance appraisal treated it as a measurement process and more toward a judgemental approach (Murphy \& Cleveland, 1995) whilst more contemporary approaches (Rusli Ahmad, 2003) 
are more concerned with information processing within the decision-making process, and yet more toward a developmental approach. In this context, Armstrong and Baron (1998) stressed the importance of looking at performance appraisal as a participative process (coaching, mentoring, helping, facilitating, and counselling), rather than a judgmental review. Performance appraisal is done for various purposes, such as for professional and career development, accountability, linked with pay and dismissal, and also as a useful mechanism to determine salary increment and promotion purposes (Abdul Aziz, 1999). Performance appraisal activity in Malaysia is a continuous process of evaluating every employee's performance, which begins in January and ends in December every year. The system involves several steps, which can be considered as continuous, however periodic. The whole circle of the process is as shown in Figure 1.

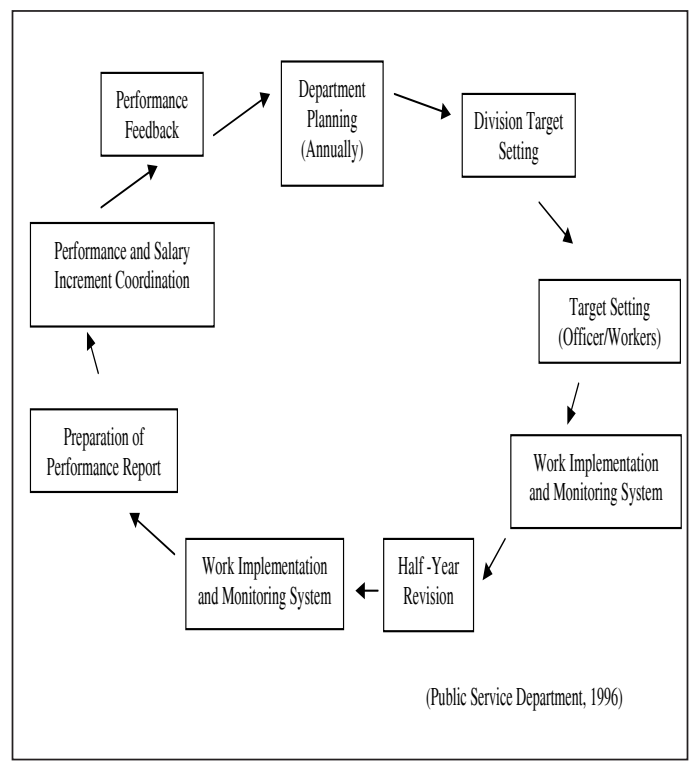

Figure 1: Performance Appraisal Process in the Malaysian Public Service

\section{COGNITIVE PROCESSING MODELS (CPM)}

The information theory model of human behaviour considers the human organism as a communication system (Ostrom, Pryor, \& Simpson, 1981). The model consists of a source, a transmitter, a channel, and a destination. At the transmitter, information is encoded and sent along the channel to the destination, where it is then decoded (Hamington \& Warburton, 1979). There were other various theories explaining the processing system involved in performance appraisal activities, such as cognition theory, implicit theory, causal attribution theory, signal detection theory, implicit personality theory, and instinct theory (Lord, 1985; Sulsky \& Day, 1992). These theories are considered important because they have strong links with CPM, which is the research focus in this study.

Cognitive processing broadly includes almost any activity involving the mental manipulation or storage of information (Murphy \& Cleveland, 1995). Models of performance appraisal have assumed that appraisal largely concentrates on cognitive processing activities (Landy \& Farr, 1980, 1983; Feldman, 1981; Ilgen \& Feldman, 1983; DeNisi, Caffrey, \& Meglino, 1984). These models explicitly treat a rater as an active seeker of information, and are often referred to as social information processing models because raters are processing information about people rather than objects (DeNisi et al., 1984). How a rater searches for information will determine what behaviour the rater observes. If important information is not observed, incorrect evaluations of ratees may be made. Several conceptualisations of the cognitive processes involved in performance appraisal have been proposed (Landy \& Farr, 1980, 1983; Cooper, 1981; Feldman, 1981; Ilgen \& Feldman, 1983; DeNisi et al., 1984; Wofford \& Goodwin, 1990; Cardy \& Dobbins, 1994; Corner, Kinicki, \& Keats, 1994; Murphy \& Cleveland, 1995; Beck De, O’Sullivan, \& Boh Le, 1995; DeNisi, 1996). Rusli Ahmad (2003) concluded that CPM can be summarised to include several important steps, which are observation, categorisation, storage, retrieval, integration, and decision, as shown in Figure 2. 


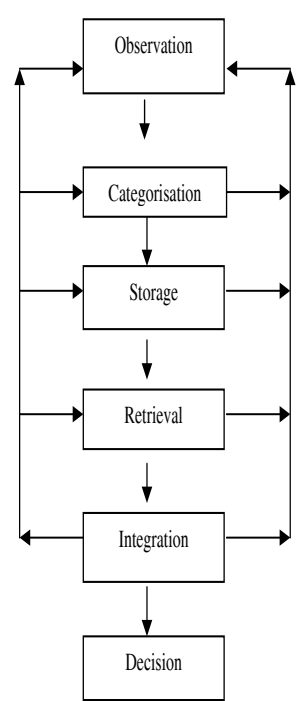

(Rusli Ahmad, 2003)

Figure 2: CPM in Performance Appraisal

According to CPM (Rusli Ahmad, 2003) shown in Figure 2, the first step in CPM is the observation of ratees by raters. Observation is defined as carefully observing behaviour for performance evaluation, so that accurate information is stored in memory (Murphy \& Cleveland, 1995). The purpose of observation can have a direct impact on the accuracy of behaviour ratings. The second step is categorisation, which means information is simplified by categorising it into dimensions that represent the complexity of observed behaviour in a relatively simple form. Categorisation depends on the similarity between a target and each categories that is available to the rater. Next the storage step refers to the process by which sensory information is retained in memory. This process involves both short-term working memory and long-term memory. The fourth step, retrieval, incorporates the process by which stored information is recovered. Retrieval procedures involve recall and recognition where recall represents a relatively unstructured effort to retrieve information and recognition represents an attempt to determine whether a stimulus that is present in working memory matches anything that is stored in long-term memory. Integration of different pieces of information happens through encoding, storage, and retrieval. Integration of information about present performance with information about previous and subsequent performance can lead to either assimilation or contrast effects. The final step is decision and it can be influenced by the rater's judgement, and should integrate all the stages of the model as described. It is at this stage that all the factors previously identified are most likely to influence the effectiveness of an overall appraisal. This process is in line with information processing theories which gives emphasis on the way information is collected. The information theory model of human behaviour considers the human organism as a communication system (Ostromet al., 1981). The model consists of a source, a transmitter, a channel, and a destination. At the transmitter, information is encoded and sent along the channel to the destination, where it is then decoded. It is clear that the important element in this model is the processing of information, which gets through from one sequence to another and involves the cognitive aspect of the person (Hamington \& Warburton, 1979)

\section{RESEARCH OBJECTIVES}

This study aimed to identify a CPM of the raters in the MPS performance appraisal system. To achieve this aim, the cognitive maps of the novice and expert raters were explored. In particular, the study gought to answer the following four research questions:

1. What are the novice raters' cognitive maps in the performance appraisal system in the Malaysian Public Service?

2. What are the expert raters' cognitive maps in the performance appraisal system in the Malaysian Public Service?

3. What are the differences between the novice and expert cognitive maps on cognitive processing model in the Malaysian Public Service? 
4. What are the differences between the cognitive processing model in the Malaysian Public Service and the cognitive processing model in the theoretical framework?

\section{DESIGN AND METHOD}

A qualitative research approach was used to gain understanding of the raters' CPM and it is meaningfulness, because qualitative research is situational or contextual, and aims at discovering meaning, giving explanations, and describing the situation, phenomenon, problem, or event (Kumar, 1998). In this study, in-depth semi-structured cognitive mapping interview techniques (Spicer \& Sadler-Smith, 2000) were undertaken to construct causal cognitive maps of raters. A cognitive map is a graphical representation of an individual's understanding of a particular issue, domain, or problem (Spicer \& Sadler-Smith, 2000), which if elicited properly, potentially allows for deeper and more integrative understanding and insights for the researcher. These were then subsequently explored for evidence of the CPM.

The research took place in the Kota Setar Education District, Malaysia. A total of 11 expert and 11 novice appraisers were identified. Respondents were selected from senior school staff directly involved with appraisal. Participation was voluntary. Interviews took place in the appraiser's own place of work, and lasted between 45 minutes and an hour and a half. Participants were asked to describe and explain, with minimal interruption, their practice when undertaking performance appraisals. No direct mention was made of cognitive processing models. One-to-one cognitive mapping interviews were undertaken between the researcher and respondent focusing on the appraisal decision process. All the individual school teachers were assured of anonymity. The interviews began with the researcher asking the participants to describe what they thought were the key elements or concepts of the issue under discussion.
Interviews were recorded without prejudice by the interviewer on Post-It notes, using the individual's own terminology. The individuals were allowed to speak with minimal interruption until they "dried-up", or indicated that they felt they had generated enough concepts they thought were related in describing the nature of this relationship. This allowed the interviewer to define causal links between the concepts, which describe the lines of influence that exist between them. In practice, this was done by transferring Post-It notes to a sheet of paper. Tapes were reviewed to ensure that they concurred with the image and information obtained. Interviews were undertaken and maps initially produced in Malay (so they could be verified by respondents), and then translated into English and checked independently. The outcome of each interview consisted of a causal cognitive map, which represented that individuals' understanding of their actions within the appraisal process. These maps were then subsequently explored for evidence of participants' cognitive processing models. These maps were subsequently explored by the researchers for evidence of the CPM as described in Figure 2.

\section{RESPONDENT PROFILE}

Two groups of raters were identified; First Rater Officer (FRO) and Second Rater Officer (SRO). To differentiate the raters, as to whether they were novices or experts, certain criteria had to be fulfilled. The criteria for novice raters included less than five years' experience as a FRO or SRO, less than 15 years' length of service in the public service, and did not attend the training courses on the performance appraisal process. An expert rater is a respondent who has served in the position as a FRO or SRO for at least five years or more, has 15 years and above length of service, and has attended any training courses on the performance process. Five years was used as a cut-off point because it is acceptable to recognise the raters' skill, knowledge and experience, which was also used before by other researchers (Che 
Wil, 1998). Experts have better knowledge on the specific domain compared to novices (Glasser \& Chi, 1998; Petel \& Groen, 1991). A novice can be defined as an individual who is still in the learning process of obtaining specific skills of the domain. Novices are still new in that specific field, have less knowledge and experience, and use a backward reasoning and a poor method of assessment (Fisher, 1991; Petel \& Groen, 1991).

Of the total of 22 respondents ( 11 novices and 11 experts) involved in the semi-structured interview, $50.0 \%(\mathrm{n}=11)$ were male and $50.0 \%$ $(n=11)$ were female. With regard to the ethnic origin, $86.3 \%(n=17)$ were Malays and $11.5 \%$ $(n=5)$ were Chinese. In terms of age, $54.6 \%(n=12)$ were below 45 years old, while $45.4 \% \quad(n=10)$ were 45 to 55 years old. For the educational level, only $13.6 \%(n=3)$ of respondents had completed a Master's degree and the rest had a Bachelor's degree. In terms of current post, $22.7 \%(\mathrm{n}=5)$ were school principals, $45.5 \%(n=10)$ were deputy principals, and $31.8 \%(n=7)$ were senior teachers. Concerning length of time in public service, $68.2 \%(n=15)$ had served 16 to 20 years, while the remainder 21 to 25 years. Respondents were also asked to indicate their role in the implementation part of the appraisal decision. The data showed that $50.0 \%(n=11)$ of respondents were FRO, while $50.0 \%(n=11)$ were SRO.

\section{ANALYSIS}

This section discusses the output of the cognitive maps of the raters. A map consists of an individual causal cognitive map representation of their understanding of CPM. An example of the causal cognitive maps and map description representing the novice and expert raters' perspective of CPM in the decision-making process is presented in Appendix 1. Concepts identified were based on the key words or concepts which raters expressed or were identified in the semi-structured cognitive mapping interview, and after the coding process. These maps then were analysed to examine the practice of CPM steps by the raters in the decisionmaking process. The arrows show the links and relationships between the concepts, with causality of these relationships expressed by the direction of the arrows. For example, an arrow from ' $\mathrm{X}$ ' to ' $\mathrm{Y}$ ' denotes that ' $\mathrm{X}$ ' leads to, influences, or affects ' $\mathrm{Y}$ ', or ' $\mathrm{Y}$ ' is dependent upon or follows ' $\mathrm{X}$ '. A double-headed arrow denotes co-dependence, where influence is shared or works both ways. The action of the influence in relationship is also expressed. The negative influence is shown by the inclusion of a minus sign (-) next to the arrow, positive influence is shown by the absence of sign. Validity of the data and reliability of the results were taken care of by the researcher by following a systematic process of data analysis. The researcher performed the data analysis under supervision of the expert. Proper training on how to use Decision Explorer was made with the founder and the provider of the software. During the pilot study, continuous discussion was made with the expert and the semi-structured cognitive mapping interview was made based on the best practice suggestion by Huff (1990).

\section{Cognitive Map Descriptive Statistics}

Table 1 shows a summary of concepts identified by novice raters in their cognitive maps. The analysis was based on the six steps identified in the CPM. The maps were the output from the use of the Decision Explorer software (Banxia, 1994). The numbers of concepts or key words involved for every CPM step was identified by counting the concepts involved and recognised in their individual maps. For example, from Table 1 , it can be understood that Novice1 (N1) has eight concepts/key words in explanation of the observation step, two in categorisation, while for storage, only six concepts/key words were involved. N1 has only three concepts/keywords in the retrieval step, 18 concepts/key words in the integration step, and seven during the final decision step. A total of 44 concepts were involved, and the most concepts/keywords were in the integration step. This may indicate how complex the integration step was for N1 in his/ her performance appraisal decision. 
Table 2 shows the concept links for individual cognitive maps. This aspect explains the relationship between the concepts involved. For example, N1 has nine concepts links for observation, only one link for categorisation, five concepts in relationship for storage, five concepts related to each other for retrieval, a high 20 concept links for integration, and 10 concepts are related to each other for decision. These concept links were identified based on the arrows coming in and going out for the N1 cognitive map and among the CPM steps involved. Based on Table 2 , it can be seen that in terms of the relationship between the concepts, N6 has the biggest number of links concepts (78 links), while the lowest number of links (14) came from N8.

Table 1: Analysis of Novice Raters' Concepts by CPM Stages

\begin{tabular}{cccccccc}
\hline Rater/Stages & Obs & Cat & Sto & Ret & Int & Dec & Total \\
\hline N1 & 8 & 2 & 6 & 3 & 18 & 7 & 44 \\
N2 & 13 & 4 & 6 & 6 & 3 & 8 & 40 \\
N3 & 15 & 6 & 0 & 4 & 11 & 14 & 52 \\
N4 & 17 & 3 & 6 & 8 & 7 & 12 & 53 \\
N5 & 10 & 0 & 4 & 0 & 12 & 4 & 32 \\
N6 & 3 & 9 & 8 & 7 & 16 & 13 & 56 \\
N7 & 7 & 2 & 3 & 3 & 13 & 14 & 42 \\
N8 & 2 & 2 & 0 & 3 & 3 & 8 & 19 \\
N9 & 7 & 0 & 6 & 4 & 9 & 7 & 33 \\
N10 & 12 & 0 & 9 & 11 & 12 & 7 & 52 \\
Total & 94 & 28 & 48 & 49 & 104 & 94 & 423 \\
Mean & 9.4 & 2.8 & 4.8 & 4.9 & 10.4 & 9.4 & 42.3 \\
\hline
\end{tabular}

Key: $\mathrm{Obs}=$ observation, $\mathrm{Cat}=$ categorisation, $\mathrm{Sto}=$ storage, $\mathrm{Ret}=$ retrieval, $\mathrm{Int}=$ integration, $\mathrm{Dec}=$ decision $\mathrm{N}=$ refers to novice rater, $1=$ refers to respondent 1 (the same explanation applies to other respondents)

Table 2: Novice Raters' Map Links

\begin{tabular}{crrrrrrr}
\hline Rater/Stages & $\begin{array}{r}\text { Obs } \\
\text { link }\end{array}$ & $\begin{array}{r}\text { Cat } \\
\text { link }\end{array}$ & $\begin{array}{r}\text { Sto } \\
\text { link }\end{array}$ & $\begin{array}{r}\text { Ret } \\
\text { link }\end{array}$ & $\begin{array}{r}\text { Int } \\
\text { link }\end{array}$ & $\begin{array}{r}\text { Dec } \\
\text { link }\end{array}$ & Total \\
\hline N1 & 9 & 1 & 5 & 5 & 20 & 10 & 50 \\
N2 & 18 & 3 & 5 & 10 & 2 & 16 & 54 \\
N3 & 15 & 7 & $(1)$ & 5 & 14 & 18 & 58 \\
N4 & 19 & 2 & 9 & 10 & 11 & 14 & 65 \\
N5 & 14 & $(1)$ & 3 & 0 & 11 & 3 & 32 \\
N6 & 3 & 14 & 10 & 6 & 32 & 13 & 78 \\
N7 & 8 & 1 & 2 & 2 & 15 & 28 & 56 \\
N8 & 1 & 1 & 0 & 3 & 2 & 7 & 14 \\
N9 & 10 & 0 & 5 & 3 & 8 & 11 & 37 \\
N10 & 11 & 0 & 10 & 10 & 12 & 6 & 49 \\
Total & 108 & 29 & 49 & 54 & 127 & 126 & 493 \\
\hline
\end{tabular}

Key: Obs = observation, Cat $=$ categorisation, Sto $=$ storage, Ret $=$ retrieval, Int $=$ integration, Dec $=$ decision, ( ) = indicates negative concepts, $\mathrm{N}=$ refers to novice rater, $1=$ refers to respondent 1 (the same explanation applies to other respondents) 
Table 3: Analysis of Expert Raters' Concepts by CPM stages

\begin{tabular}{cccccccc}
\hline Rater/Stages & Obs & Cat & Sto & Ret & Int & Dec & Total \\
\hline E1 & 12 & 4 & 6 & 8 & 12 & 7 & 49 \\
E2 & 11 & 6 & 7 & 7 & 11 & 15 & 57 \\
E3 & 15 & 1 & 1 & 1 & 20 & 16 & 54 \\
E4 & 10 & 7 & 7 & 4 & 7 & 12 & 45 \\
E5 & 13 & 5 & 5 & 5 & 19 & 11 & 55 \\
E6 & 14 & 4 & 4 & 4 & 12 & 7 & 51 \\
E7 & 24 & 6 & 6 & 10 & 11 & 4 & 62 \\
E8 & 10 & 8 & 8 & 12 & 10 & 6 & 52 \\
E9 & 7 & 3 & 10 & 5 & 8 & 6 & 39 \\
E10 & 9 & 8 & 8 & 7 & 12 & 9 & 54 \\
E11 & 22 & 4 & 8 & 8 & 11 & 16 & 69 \\
Total & 147 & 56 & 71 & 71 & 133 & 109 & 587 \\
Mean & 13.4 & 5.1 & 6.5 & 6.5 & 12.1 & 9.9 & 53.4 \\
\hline
\end{tabular}

Key: Obs $=$ observation, Cat $=$ categorisation, $\mathrm{Sto}=$ storage, Ret $=$ retrieval, $I n t=$ integration, Dec $=$ decision, $\mathrm{E}=$ expert rater, $1=$ refers to respondent 1 (the same explanation applies to other respondents)

Table 4: Expert Raters' Map Links

\begin{tabular}{cccccccc}
\hline Rater/Stages & $\begin{array}{c}\text { Obs } \\
\text { link }\end{array}$ & $\begin{array}{r}\text { Cat } \\
\text { link }\end{array}$ & $\begin{array}{r}\text { Sto } \\
\text { link }\end{array}$ & $\begin{array}{r}\text { Ret } \\
\text { link }\end{array}$ & $\begin{array}{r}\text { Int } \\
\text { link }\end{array}$ & $\begin{array}{c}\text { Dec } \\
\text { link }\end{array}$ & Total \\
\hline E1 & 15 & 3 & 5 & 7 & 13 & 9 & 52 \\
E2 & 10 & 5 & 6 & 7 & 10 & 14 & 52 \\
E3 & 23 & 0 & 0 & 0 & 39 & 27 & 89 \\
E4 & 13 & 14 & 5 & 3 & 8 & 23 & 65 \\
E5 & 13 & 4 & 1 & 4 & 19 & 10 & 51 \\
E6 & 14 & 4 & 10 & 9 & 4 & 11 & 50 \\
E7 & 24 & 5 & 11 & 11 & 16 & 3 & 70 \\
E8 & 10 & 7 & 5 & 11 & 15 & 7 & 55 \\
E9 & 9 & 2 & 11 & 4 & 7 & 6 & 39 \\
E10 & 9 & 7 & 8 & 8 & 24 & 8 & 66 \\
E11 & 27 & 4 & 8 & 8 & 12 & 15 & 73 \\
Total & 167 & 54 & 70 & 72 & 167 & 133 & 662 \\
\hline
\end{tabular}

Key: Obs $=$ observation, $\mathrm{Cat}=$ categorisation, $\mathrm{Sto}=$ storage, $\mathrm{Ret}=$ retrieval, $\mathrm{Int}=$ integration, $\mathrm{Dec}=\mathrm{decision}$ $\mathrm{E}=$ expert rater, $1=$ refers to respondent 1 (the same explanation applies to others respondents)

Table 3, on the other hand, shows the expert raters' cognitive map concepts. The highest individual concepts were 69 (E11), while the lowest were 39 (E9). This table gives a clear picture of understanding on the concepts involved in the performance appraisal decision-making process and the emphasis on those particular stages (observation, categorisation, storage, retrieval, integration, and decision).

Table 4 shows the concept links for expert raters. From the table, Expert 3 (E3) was found to have the highest number of concepts links (89), and the lowest number of links was for E9 (39). 


\section{RESULTS}

Discussion of the output of the semi-structured interviews is presented below. This is organised around sub-topics reflecting the research aims, objectives, and research questions. The intention was to simplify the discussion and contribute to a better understanding of the research findings.

\section{What are the Raters' (Novice and Expert) Cognitive Maps?}

One of the main aims in this study was to explore the raters' cognitive maps on the performance appraisal decision-making process. Individual raters' cognitive maps showed all the concepts followed and involved in the process, and are based on causal concept relationships. Every individual cognitive map is different in terms of the concepts involved, concepts for each step, the total concepts, and concept links. As a result, every individual has a personal cognitive map, each with its own complexity. The first research question was regarding the individual rater's cognitive map in the performance appraisal decision. Explanation and discussion on how a novice and expert rater performs his/her task are reported in Appendices $1 \mathrm{~A}$ and $1 \mathrm{~B}$ as an example.

\section{Differences of Cognitive Maps between Two Groups of Raters}

There are a lot of differences in the two groups of raters identified in the performance appraisal decision. Comparison of the numbers of total concepts between the two groups showed that expert raters have more total concepts compared with novices. The expert raters obtained 587 (see Table 3), while the novice raters only have 423 concepts (see Table 1). One potential explanation of this finding is that expert raters are more knowledgeable and experienced in performing their responsibilities. This finding implicitly sends the message that expert raters are more skilful and knowledgeable particularly when performing their job. Novice raters would have a more general approach on that.

One aspect of cognitive maps of the raters which can be compared was the realisation of CPM steps in the performance appraisal decision. It is clear from Table 1 that novice raters while making the performance appraisal decision follow almost all the steps in the CPM. It seems that the sequence of emphasis in descending order for all the six steps was led by integration (104 concepts), followed by decision and retrieval (94 concepts and 49 concepts), storage (48 concepts), and ending with categorisation ( 28 concepts) (see Table 1). However, the novice raters N5, N8, N9, and N10 showed that they did not follow certain steps in CPM. N5 was found not to go through categorisation and retrieval steps in his/ her performance appraisal decision, rater N8 did not follow the storage steps, while raters N9 and N10 did not mention the categorisation step. The expert cognitive maps can be seen in Table 3. From this table, it was clear that expert raters while making a performance appraisal decision follow all the steps in the CPM. Every expert rater, without doubt, recognised and was aware of the six steps in CPM. The only difference was the emphasis on each of the CPM steps. For the expert raters, it seemed that the sequence of emphasis for each step was led by observation (147 concepts), followed by integration (133 concepts), decision (109 concepts), storage (71 concepts), retrieval (71 concepts), and ending with categorisation (56 concepts) (see Table 3).

In terms of concept links, for the novice raters the integration step has the highest score (127 concepts), followed by decision (126), observation (108), retrieval (54), storage (49) and categorisation (29). The results also showed that novice raters take a lot of consideration when integrating the information before arriving at a decision. Decision takes next place, followed by observation. This shows that the observation step is very important in collection of information in the decision-making process. For the expert raters, the integration step has the highest score of concept links (174 concepts), followed by observation, 
decision, storage, retrieval, and categorisation. In this regard, the results also showed that expert raters take a lot of consideration when integrating the information before arriving at decisions. Observation takes second place, and this means that the observation step is very important in collection of information in the decision-making process.

In summary, the findings revealed that novice and expert raters show their own unique models in cognitive maps. Table 5 summarises the mean numbers of concepts in CPM for novice and expert raters. This table gives a clear picture of the emphasis of novice and expert raters on CPM stages in the performance appraisal decision.

Table 5: Total Concepts Mean Score for CPM Stages by Raters

\begin{tabular}{lrr}
\hline \multicolumn{1}{c}{ CPM stages } & $\begin{array}{c}\text { Novices } \\
\text { Score }\end{array}$ & $\begin{array}{c}\text { Experts } \\
\text { Score }\end{array}$ \\
\hline Observation & 9.4 & 13.4 \\
Categorisation & 2.8 & 5.1 \\
Storage & 4.8 & 6.5 \\
Retrieval & 4.9 & 6.5 \\
Integration & 10.4 & 12.1 \\
Decision & 9.4 & 9.9 \\
Total & 42.3 & 53.4 \\
\hline
\end{tabular}

Table 5 shows several patterns of the CPM stages for novice and expert raters. Firstly, novices and experts give stronger emphasis on observation, integration, and decision. Secondly, they give less emphasis on the other CPM stages of categorisation, storage, and retrieval.

From Table 1, individual cognitive maps of the raters can also be compared. The individual cognitive maps for the novice raters showed that N6 has the highest score (56 concepts), while N8 has the lowest (19 concepts). The range is thus 37 concepts (56-19) (refer to Table 1). For the expert raters, E11 scores the highest (69 concepts), and E9 the lowest (39 total concepts). The range between the two is 30 (69-39) (refer to Table 3). This finding showed that expert raters are more exposed to this particular task and without doubt are more professional (serving in the position at least five years or more, and has attended training courses of on performance appraisal).

Another aspect that can be compared for both raters was complexity $(\beta)$ and density $(\gamma)$ of the maps. The mathematical basis for these measures is discussed in Appendix 2. Complexity $(\beta)$ gives the mean number of links per concept in each map, and the higher the $\beta$-score, the more complex the map (Harary, 1969; Eden, Ackermann, \& Popper, 1992). Density $(\gamma)$ compares the actual number of links present in a map with the theoretical maximum number possible for the number of concepts in the map contains. The closer $\gamma$ approaches 1.0, the more the map approaches optimal connectivity (Daniels, Johnson, \& Chernatory, 1994). For novice raters, Table 6 highlights the variety obtained in the context of individual understanding for novice raters; they incorporate between 19 (N8) and 56 (N6) concepts, and between 14 (N8) and 78 (N6) map links. For the novice raters, in terms of complexity, individual understanding ranged from a low of 0.74 (N8) links per concept to a high of 1.39 (N6). The individual maps' density $(\gamma)$ ranges from $0.018(\mathrm{~N} 10)$ to $0.041(\mathrm{~N} 8)$.

Complexity $(\beta)$ and density $(\gamma)$ of the maps for expert raters are shown in Table 7. In terms of complexity, individual models ranged from a low sore of 0.91 (E2) links per concept, to a highest score of 1.56 (E3). Rater E3 seemed to have the most complexity in his/her cognitive map. The individual understanding of density $(\gamma)$ ranged from $0.010(\mathrm{E} 2)$ to $0.033(\mathrm{E} 4)$. The results indicated that respondent $\mathrm{E} 4$ has the highest density in his/her cognitive map. Novice and expert raters showed their own unique models in cognitive maps. Table 7 summarises the mean number of concepts in CPM for novice and expert raters. This table gives a clear picture of the emphasis of novice and expert raters on CPM steps in the performance appraisal decision. From the table, it is clear that novices and experts give stronger emphasis on observation, integration, and decision. 
Table 6: Novice Raters' CPM Stages Summary

\begin{tabular}{lccccccccccc}
\hline & $\mathrm{N} 1$ & $\mathrm{~N} 2$ & $\mathrm{~N} 3$ & $\mathrm{~N} 4$ & $\mathrm{~N} 5$ & $\mathrm{~N} 6$ & $\mathrm{~N} 7$ & $\mathrm{~N} 8$ & $\mathrm{~N} 9$ & $\mathrm{~N} 10$ & Mean \\
\hline Concepts & 44 & 40 & 52 & 53 & 32 & 56 & 42 & 19 & 33 & 51 & 42.2 \\
Links & 50 & 54 & 58 & 65 & 32 & 78 & 56 & 14 & 37 & 49 & 49.3 \\
$\beta$ & 1.14 & 1.35 & 1.16 & 1.23 & 1.00 & 1.39 & 1.33 & 0.74 & 1.12 & 0.94 & 1.14 \\
$\gamma$ & 0.026 & 0.035 & 0.022 & 0.024 & 0.033 & 0.025 & 0.033 & 0.041 & 0.035 & 0.018 & 0.029 \\
\hline
\end{tabular}

Key: $\beta$ : complexity, $\gamma$ : density, $\mathrm{N}=$ novice rater, $1=$ refers to respondent 1 (can apply to others)

Table 7: Expert Raters' CPM Stages Summary

\begin{tabular}{lcccccccccccc}
\hline & E1 & E2 & E3 & E4 & E5 & E6 & E7 & E8 & E9 & E10 & E11 & Mean \\
\hline Concepts & 49 & 57 & 54 & 45 & 55 & 51 & 62 & 52 & 39 & 54 & 69 & 53.36 \\
Links & 52 & 52 & 89 & 65 & 51 & 50 & 70 & 55 & 39 & 66 & 74 & 60.27 \\
$\beta$ & 1.06 & 0.91 & 1.56 & 1.44 & 0.92 & 0.98 & 1.12 & 1.06 & 1.00 & 1.22 & 1.07 & 1.12 \\
$\gamma$ & 0.022 & 0.016 & 0.031 & 0.033 & 0.017 & 0.019 & 0.018 & 0.021 & 0.026 & 0.023 & 0.016 & 0.022 \\
\hline
\end{tabular}

Key: $\beta$ : complexity, $\gamma$ : density, $E=$ refers to expert rater, $1=$ refers to expert respondent number 1

\section{Examination of CPM Steps Suggested by Scholars/ Researchers}

The research findings showed that six steps in $\mathrm{CPM}$ are practised and recognised by the raters in the MPS performance appraisal decision. The important point to highlight here is that every step has its own weightage, and raters are open to give any emphasis to what they consider important. It is clear that the research findings have met the research objectives in this phase, namely to examine the CPM suggested by other scholars and researchers (Fahey \& Narayanan, 1989; Fournier, 1996). Evidence was found that novice and expert raters recognised the existence and the importance of CPM steps in their decision-making process on PAS.

Experts and novices however, do show similar levels of relative importance for the six cognitive processing model steps. Whilst the absolute number of concepts does differ, experts and novices both rank observation, integration, and decision above categorisation, storage, and retrieval. This difference appears to relate to an "overt-covert" split between the stages of the processing model. Observation, integration, and decision are overt stages of the cognitive processing model in appraisal that are more evident or explicit both for the appraiser and in their practice at the workplace. Observation is practical, whilst integration involves comparisons of performance and the decision has tangible outcomes. The other three stages (categorisation, storage, and retrieval) are more covert, however. These are genuinely internal cognitive processes, that whilst they may be aided by documentary records (as many of the respondents here indicated), they are undertaken individually and often have a highly implicit element within them.

\section{DISCUSSION}

One of the important findings was regarding the cognitive maps of the raters. Individual cognitive maps showed that respondents have their own cognitive map which has unique characteristics in relation to each other. This finding is highly related with the study by Fahey and Narayanan (1989), which emphasised that the content and style of the 
maps can be different and change considerably from time to time, based on the content, context, and other influences. Fournier (1996) supported these facts in their study on managers' cognitive maps on personnel change. They found that these maps are shifting from normal to transaction period modes of thought and behaviour in response to the new situation. This finding supports research by Foo (1995), who found that $78 \%$ of all managers surveyed agreed positively with the statement that they did handle the decision-making process differently. The study by Spicer and SadlerSmith (2000) supported this, by showing that each individual manager's cognitive maps were different with respect to a specific organisational map being normal, and it represents genuine rater understanding of the task undertaken.

This finding is in relation with the objectives of using cognitive mapping techniques that try to make the structure of thinking more visible (Huff, 1990). These maps are potentially important, because they provide a way to structure and simplify thoughts and beliefs, to make sense of them, and to communicate information about them (Huff, 1990). In this context, raters' cognitive maps can be used as frame of reference to explain the information processing process involve in the decision-making process on employee performance. It is relatively easy to see how each of the concepts and causal relationships relate to each other, and to see the overall structure of the whole set. In this study, all raters have their own cognitive maps, and by looking at the maps, it is clearly shown how the performance appraisal process works, and the structure of the raters' thinking process. In order to ensure that these cognitive maps produced are effective and bias is reduced, the researcher needs to be trained, competent, and confident with the techniques. In this context Fiol and Huff (1990) argued that the map will become superficial and uncommunicative if the researcher is not competent in using that technique. They pointed out that effectiveness of cognitive maps depends on the skill of the researcher.

Another important finding can be seen in the raters' group cognitive maps. In terms of the awareness and practising of CPM steps in the performance appraisal decision, the result showed that expert raters practise all the CPM steps in their performance appraisal decision as compared to novice raters. This result is in parallel with the research proposition by DeNisi et al. (1984), and Murphy and Cleveland (1995). For the novice raters, the results indicated that they are aware of the importance of CPM steps in the performance appraisal decision. The results showed that the majority of novice raters $(60 \%)$ practised all the six steps in CPM. Only 40\% did not follow all the steps, and they did not practise the categorisation, storage, and retrieval steps. It should be noted that the categorisation step was recognised by scholars and researchers (Murphy \& Cleveland, 1995) as a difficult task to follow, because it involves a complex process and is difficult to explain. Sometimes raters did not realise it in their cognitive map concepts, but in reality they do just that. It is important to highlight here that scholars and researchers (Feldman, 1981; Landy \& Farr, 1983, 1980; Wofford \& Goodwin, 1990) also, in their discussion about CPM, only discussed certain CPM steps which they felt very important. On the other hand, these results can be related to the lack of experience as raters for the novice raters. Expert raters have experience of more than five years as raters, while novice raters have fewer in comparison. In terms of training as raters, only expert raters have proper and adequate training. Analoui (1992), in his study, proved that training is one of the major approaches to enhance raters' competence. Research on training and impact on the performance appraisal decision can also be seen in the work of Day and Sulsky (1995), Murphy and Cleveland (1995), Stamoulis and Hanenstein (1993), and Woehr (1991). Woehr (1991) argued that the primary goal of training is to train raters to share and use common conceptualisations of performance when making evaluations. Feldman (1986) suggested that training should provide raters with uniform and valid schema and prototypes. If all raters know what good performance looks like and agree in their definition of good, average, and poor, it is likely the quality of rating data would improve dramatically. Feldman (1986) also suggested that frame-of-reference training, 
as suggested by Bernardin and Beatty (1984), be used. Analoui (1992) identified three categories of managerial skill, which he argued to be essential for the successful performance of managers. He stressed analytical and self-related skills, peoplerelated skills, and task-related skills. In this context of study, maybe task-related skills are appropriate to enhance raters' skill in making the performance appraisal decision. Many writers (Beardwell \& Holden, 1997; Yong, 1998) also came up with ideas of how vital these two activities are in human resource management, i.e. training and development, and how important their effectiveness of implementation is for any organisation. Training, undeniably, has been proven to be one of the mechanisms to enhance rater ability and accuracy of rating. Research by Adnan (1999), Ford, Smith, Sego, and Quinones (1993), Ghulam (1993), Scarpello and Ledvinka (1988), and Schoenfeld (1994), supported the importance of training to enhance raters' ability and accuracy of rating. They found the evidence that rater training improves rating and the performance appraisal decision. It is hoped that training programmes can be arranged by the Public Service Department (PSD) Malaysia, for all the raters involved, and also for the potential rating officers.

One of the important findings for the group cognitive maps was on the issue of how information is processed. This issue deals with the information processing system which occurs in the rater's mental exercise or their mind. It is hard to understand these process-specific terms, but the steps suggested in CPM help a lot in terms of understanding the process. This is one of the big challenges to scholars and researchers when they come to discuss the issue of what actually happens in raters' mental process. Research on 28 laboratory experiments by DeNisi (1996) was in line with this emphasis, where it was found that raters do engage in systematic search for information.

Together, cognitive maps of CPM steps of novice and expert raters provided interesting findings. The empirical results showed that observation, integration, and decision were recognised and have been followed 100\% by novice and expert raters, while storage, retrieval, and categorisation were found to be less emphasised. This does not mean raters did not practise this step, only the emphasis was less. These three steps had the greatest impact on raters during their decision-making process. The observation step was found to be very important to raters, to observe behaviour of the ratees in the work place. This step is important to answer the question whether raters generally acquire enough information prior to making the performance decision. Raters are responsible for getting as much information from observation activities, to sort relevant from irrelevant information, and to handle it systematically. Information (quantitative and qualitative) is a valuable commodity, and does add considerable value to the decisionmaking process. On this point, Gatewood and Field (1990) stressed the value of obtaining as much information about ratees as possible prior to making a decision. This information acquisition process work is very active and uses multiple ways and methods (Tornow, 1993). The process is very important, and becomes a prerequisite step before other steps in CPM can be followed. Feldman (1981), in this context, stressed the importance of information acquisition, which was based on previous contact between raters and ratees. Contact gives more chance for raters to observe relevant performance. DeNisi et al. (1984), in this context, found that the raters need different aspects of information at this stage of rating. They stressed consistency of information, distinctiveness of information, consensus information, and "mixed" information. One important aspect which Murphy and Cleveland (1995) stressed on was the quality of observation. Raters in this context should try to avoid "irrelevant" observation. Raters may infer behavioural details from their evaluation, rather than base their evaluation on the total set of behaviour. It means they select certain aspects that suit the decision process. Here, the purpose of observation is very important (Cafferty et al., 1986; Murphy et al., 1985, 1989; William, Cafferty, Blencoe \& Cafferty, 1985) because it will affect their information acquisition, and have direct impact on several measures of the accuracy of evaluations. 


\section{RESEARCH IMPLICATIONS}

The research findings showed that, raters in the MPS have their own unique cognitive maps explaining how CPM is undertaken in performance appraisal decisions. Different patterns and emphasis of cognitive maps were found in this study. Raters were found to concentrate more on integration, decision, and observation, and less on retrieval, storage, and categorisation. The findings showed that raters are more familiar with and keen on the three concepts of CPM: integration, decision, and observation. In fact, all the six concepts are important, and help each other to complete the CPM in the decision-making process to become more systematic, effective, and reliable. It would be better if training could be given to the raters who are involved with the system. Training, without denial, has been proven to be one of the mechanisms to enhance rater ability and accuracy of rating. The Public Service Department (PSD), Malaysia, can arrange may be training programmes for all the raters involved, and also for the potential raters. On the other hand, the PSD should also be more careful when appointing new raters in the performance appraisal decision-making process.

One of the important findings in this research is that experience can enhance performance rating. Raters who have more rating experience can perform their job better than raters with less experience. Raters' total concepts and concept links explained this. Experience seems to be a very important criterion to become a good rater (Adnan, 1999; Ford et al., 1993; Ghulam, 1993; Scarpello \& Ledvinka, 1988; Schoenfeld, 1994). The issue is how to make sure raters have enough experience regarding their job. Maybe, one of the answers is through training. Another solution may be proper planning. More senior officers should be exposed to performance appraisal process and decision, and a group of novice raters should be developed. What type of exposure and the need to prepare experience for raters should also be thought about?
What next? It is hoped that a research on CPM can be conducted in the public sector in the era of electronic government. Every public service has now moved its orientation to information technology and become knowledgebased. Perhaps a study can be planned on issue of innovations in performance appraisal like Computerised Performance Monitoring, Electronic Performance Monitoring, and e-appraisal. It would also be interesting to see cognitive maps of the raters regarding CPM in the era of a developed information and communication technology.

\section{RESEARCH LIMITATION}

Although the research has generated important and interesting findings, there were limitations and problems in this study that need to be acknowledged and addressed. There were several problems that arose during the use of cognitive mapping techniques. Face-to-face, semi-structured interviews called for a lot of skill to conduct. The researcher must be very careful with the word terms. Although there is a guideline for the questions to be asked, sometimes it is hard to control the session because the issue being discussed is very sensitive. Respondents also try to escape from giving detailed information, and it may be because the topic of discussion is very sensitive and not ready for open discussion. To avoid this type of problem, the researcher asked permission from the respondents to tape-record the interview. As an alternative the researcher used the Post-It note technique to record the interview details. Sometimes, the researcher could not make a note of what the respondent said, and was able to use the tape recorder to overcome this problem. Another limitation was because of the narrow scope of issues identified (the CPM), the time-sensitivity of models, and the fact that the elicitation process had inevitably led to changes in the cognitive maps studied. These problems limit the applicability of the results presented here outside the study. Finally, a descriptive analysis adopted in this study has its statistical limitations, which may also limit its findings. 


\section{CONCLUSION}

The results obtained and described above also have some significant implications for appraisal practice. The differences observed between the novice and expert appraisers point to the significance of ensuring effective training and experience in appraisal, as it is in this respect that the expert and novice samples differed. Appraisers need to gain practice in the decision-making process, especially in situations, where their evaluations have such potential to impact upon an employee. On the other hand the analysis of this paper indicated that there were six steps followed by novice and expert raters when performing their job appraisal: observation, categorisation, storage, retrieval, integration, and decision. The descriptive analysis carried out in this paper had highlighted that CPM exists in the MPS PAS. A Performance appraisal system was implemented, and involved the whole public service work classification in Malaysia. The paper offers a new perspective to understanding performance rating by looking at CPM of the raters. It is hoped that researchers on other issues, cultural context, and geographical background can explore important facts and steps that are involved in the decision-making process. The methodology used in the study can be applied and tested not only in the public sector but also in the private sector. As a result, the research should contribute to a better understanding of the performance appraisal process as undertaken by raters in organisations. By explaining the CPM of raters, the research has offered input for policymaking and officers in practice to improve the accuracy of performance rating.

\section{REFERENCES}

Abdul Aziz, Y. (1999). Performance appraisal: Concepts and applications, Kuala Lumpur: Sinaran Bros.

Abdul Hamid, A.S. (1999). World class public service. Kuala Lumpur: Pelanduk.

Abdul Hamid, A.S. (1996). The civil service: Towards a new era. Kuala Lumpur: Pelanduk.
Adnan, A.S.A. (1999). Human resource development: Training and development practices and related organisational factors in Kuwaiti organisation. (Unpublished Dissertation Ph.D.). University of Bradford Management Centre.

Ahmad, R., \& Spicer, D.P. (2000). Practice of performance appraisal in the Malaysian public service: Proposal for research exploring the cognitive processing model. First Symposium Graduate Management Research, Universiti Utara Malaysia (1516 November).

Analoui, F. (1992). Improving management development in developing countries: The role of the trainers. Development and Project Planning Centre New Series, 27, 14-21.

Argyris, C. (1994). Good communication that block learning. Harvard Business Review, July/ August, 77-85.

Armstrong, M. (1998). Managing people: A practical guide for line managers. London: Kogan Page.

Armstrong, M., \& Baron, A. (1998). Performance management: The new realistic. London: Institute of Personnel and Development.

Banxia (1994) Decision explorer reference manual. London: Sage/ Banxia Software.

Beck De, A., O'Sullivan, P.S., \& Boh Le, (1995). Increasing the accuracy of observer ratings by enhancing cognitive processing skills. American Journal of Pharmaceutical Education, 59 (3), 228-235.

Beardwell, I., \& Holden, L. (1997). Human resource management: A contemporary perspective, London: Financial Times/ Pitman.

Bernardin, H.J., \& Beatty, R.W. (1984). Performance appraisal: Assessing human behaviour at work. Boston: Kent.

Bratton, J., \& Gold, J. (1999). Human resource management: Theory and practice. London: Macmillan Business.

Cafferty T.P. DeNisi A.S., \& William K.J. (1986). Search and retrieval patterns for performance information: Effects on evaluation and multiple targets. Journal 
of Personality and Social Psychology, Vol. 71, pp. 672-678.

Cardy, R.L., \& Dobbins, G.H. (1994). Performance appraisal. Alternative perspectives. Cincinnati, OH: Southwestern Publishing. Che Wil, H. (1998). Teori pemprosesan maklumat. (Unpublished Master Thesis). Faculty of Cognitive Sciences and Human Development, Universiti Malaysia Sarawak, Kuching, Sarawak, Malaysia.

Cooper, W. (1981). Conceptual similarity as a source of illusory halo in job performance rating. Journal of Applied Psychology, 66 (2), 302-307.

Corner, P.D., Kinicki, A.J., \& Keats, B.W. (1994). Integrating organisational and individual information processing perspective on choice. Organisation Science, 5(3), 145173.

Daniels, K., Johnson, G., \& de Chernatory, L. (1994). Differences in managerial cognitions of competition. British Journal of Management, 5 (special issue), 21-29.

Day, D.V., \& Sulsky, L.M. (1995). Effect of frame of-reference training and information configuration on memory organisation and rating accuracy. Journal of Applied Psychology, 80(2), 158-167.

DeNisi, A.S. (1996). A cognitive approach to performance appraisal. A program of research. London: Routledge.

DeNisi, A.S., Caffrey, T., \& Meglino, B. (1984). A cognitive view of the performance appraisal process: Evidence from the field. Journal of Applied Psychology, 33(3), 360-396.

Drucker, P.F. (1994). Managing in turbulence time. Oxford: Butterworth-Heinemann Ltd.

Eden, C., Ackermann, F., \& Cropper, S. (1992). The analysis of cognitive maps. Journal of Management Studies, 29, 309-324.

Feldman, J.M. (1981). Beyond attribution theory: Cognitive processes in performance appraisal. Journal of Applied Psychology, 66(2), 127-148.

Fahey, L., \& Narayanan, V.K. (1989). Linking changes in revealed causal cognitive maps and environmental change: An empirical study. Journal of Management Studies, 26(3), 361-378.

Fiol, C.M., \& Huff, A.S. (1992). Maps for managers: Here we are? Where do we go from here?' Journal of Management Studies, 29(3), 267-285.

Fisher, J. (1991). Defining the novice user. Behaviour and Information Technology, 10(5), 441-457.

Foo P. (1998). Kognitif perspektif dalam sistem penilaian prestasi. (Unplished Master Thesis). Fakulti Sains Kognitif dan Pembangunan Manusia, Universiti Malaysia Sarawak, Kuching, Malaysia.

Ford, J.K., Smitch, E.M., Sego, D.J., \& Quinones, M.A. (1993). Impact of task experience and individual factors on training-emphasis rating. Journal of Applied Psychology, 78(4), 583-590.

Furnham, R. (1994). Does money motivate? The Sunday Times, 9 October, in The Effective Manager: Perspective and Illustrations, J. Billsberry. London: Sage.

Gatewood, R., \& Field, H. (1990) Human resource selection. Chicago: Dryden.

Ghulam, S.A.G.G. (1993). Distributive justice vs procedural justice. Perceptions of fairness of Saudi Arabian civil service employees in their performance appraisal system. (Unpublished Dissertation Ph.D.). The University of Arizona, USA.

Fournier, V. (1996). Cognitive maps in the analysis of personnel change during work role transaction. British Journal of Management, 7(1), 87-105.

Glasser, R., \& Chi, M.T.H. (1998). The nature of expertise, New Jersey. Lawrence Erbarn Associates Publisher.

Hamington, V., \& Warburton D.M. (1979). Human stress and cognition: An information processing approach. Chichester: John Wiley.

Harary, F. (1969). Graph theory. Reading: Addison-Wesley.

Huff, A.F. (Ed.) (1990). Mapping strategic thought, Chichester: Wiley.

Ilgen, D.R., \& Feldman, J.M. (1983). Performance appraisal: A process focus. Organisational Behaviour, 5(3), 141-197. 
Johnston R.J. Gregory D., \& Smith D.M. (1986). Dictionary of human geography (2nd edn.). Oxford: Blackwell.

Kumar, R. (1998). Research methodology. London: Sage.

Landy, F.J., \& Farr, J.L. (1980). Performance rating. Psychological Bulletin, 87(4), 72107.

Landy, F.J., \& Farr, J.L. (1983). The measurement of work performance: Methods, theory and applications. New York: Academic Press.

Lord, R.G. (1985). Accuracy in behavioural measurement: An alternative definition based on raters cognitive schema and signal detection. Journal of Applied Psychology, 70, 66-71.

Murphy, K.R., \& Cleveland, J.N. (1995). Understanding performance appraisal: Social, organizational and goal-based perspectives. California: Sage.

Murphy K.R. Balzer W.D. Lockhart M.C., \& Eisenman E.J. (1985). Effects of previous performance on evaluation of present performance. Journal of Applied Psychology, 70, pp. 72-84.

Murphy K.R. Philbin T.A., \& Adams S.R. (1989). Effect of purpose of observation on accuracy of immediate and delayed performance ratings. Organisational Behaviour and Human Decision Processes, 43, pp. 336-346.

Millward, N., Bryson, A., \& Forth, J. (2000). All change at work? London: Routledge.

Ostrom T.M., Pryor, J.B., \& Simpson, D.D. (1981). The organization of social information. In E. Higgins, C. Herman, \& M. Zanna (Eds.). Social cognition: The Ontario Symposium on personality and social psychology. ( $p p$. 55-68). Hillsdale, NJ: Erlbaum.

Perry, J. (1995). Compensation, merit pay, and motivation. In S.W., \& R.C. Kearney, (Eds.). Public personnel administration: Problems and prospects, Hay, New Jersey: Prentice Hall.

Petel, V.L., \& Groen, G.L. (1991). Development accounts of the transition from medical student to doctor: Some problem and suggestion. Medical Education, 25(3), 527-535.
Public Service Department (1996). Rearrangement of new performance appraisal system in the Malaysian public service. Service Circular Number 7, Year 1996. Kuala Lumpur: National Printing Department.

Rusli Ahmad. (2003). Cognitive processing model in performance appraisal decision. (Unpublished Dissertation Ph.D.). University of Bradford, UK.

Scarpello, F., \& Ledvinka, J. (1988). Personnel human resource management: Environment and functions. Massachusetts: PWS Kent.

Schoenfeld, G.A. (1994). Longitudinal field experiment and call for a new paradigm. (Unpublished Dissertation Ph.D.). University of Pittsburgh, USA.

Spicer, D.P., \& Sadler-Smith (2000). The role of mental models in individual and organisational learning, including consideration of cognitive style. (Unpublished Dissertation Ph.D.). University of Plymouth, UK.

Stamoulis, D.T., \& Hanenstein, N.M.A. (1993). Rater training and rating accuracy: Training for dimensional accuracy versus training for rater differentiation. Journal of Applied Psychology, 78 (6), 994-1003.

Sulsky L.M., \& Day D.V. (1992). Frameof-reference training and cognitive categorization: An empirical investigation of rater memory issues. Journal of Applied Psychology, 77, 501-510.

Tornow W.W. (1993). Perceptions or reality: Is multiple-perspective measurement a means or an end? Human Resource Management, (32), 221-230.

Williams K.J. DeNisi A.S. Blencoe A.G., \& Cafferty T.P. (1985). The role of appraisal purpose: effects of purpose on information acquisition and utilisation. Organisational Behaviour and Human Decision Processes, 36, 314-339.

Woehr, D.J. (1991). Performance dimension accessibility: Implications for rating accuracy. Journal of Organisational Behaviour, 12(1), 1-11.

Wofford, J.C., \& Goodwin, V.L. (1990). Effects of feedback on cognitive processing and 
choice of decision style. Journal of Applied Psychology, 75(3), 603-612.

Yong, A.K.B. (1998). Malaysian human resource management. Kuala Lumpur: Malaysian Institute of Management. 
APPENDIX 1A: Novice 1 Cognitive Processing Model in Performance Appraisal

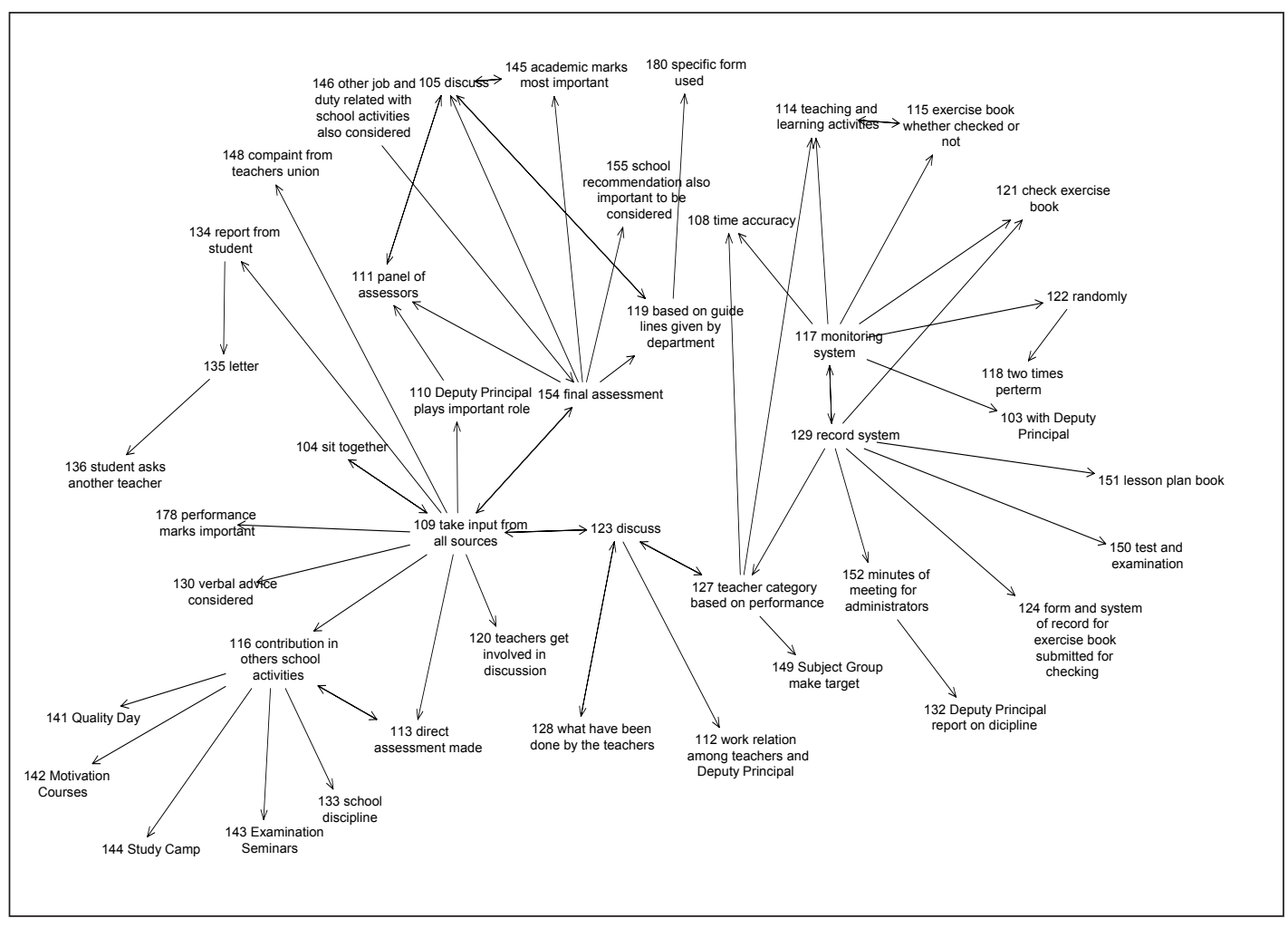




\section{Individual Novice Rater Cognitive Map Description}

Novice One explained that his/her CPM in the performance appraisal decision starts with a monitoring system. He/she monitors teaching and learning activities with help from the Deputy Principal by looking at the student exercise books. The teacher's lesson is randomly monitored twice per term. The rater checks the exercise books to determine whether the teacher checks student work or not. Student textbooks are also checked in terms of their cleanliness, and whether students bring them to class or not. All the concepts explained the observation step for Novice One. Another process followed by Novice One is recording. He/she established a record system which was used to record teachers' regularity in sending their lesson plan book for checking, tests, and examinations, exercise books, minutes of meetings, and reports on discipline. This step was called storage in CPM. Novice One explained about the categorisation step in his/her cognitive maps. He/she categorises the teacher's performance based on performance in the core business (teaching and learning activities). A teacher who becomes a Head of a subject group helps with making targets for teachers in the group and also sets the time limit. A discussion process was followed by Novice One, and he/she discusses what has been done by the teacher in his/her job. He traces work relations among teachers and the school administrator. This step can be considered as the retrieval step in CPM. The words "take input from all sources" explained the integration step in CPM followed by Novice One. From his/her cognitive map, it is clear that Novice One takes into consideration various factors (i.e., student work performance, teachers' contribution to school activities, opinion from school administrators, student opinion, and teachers' self-opinion on their performance). Teachers, the school administrator, and his/her assessors sit together and discuss the subordinates' performance. Final assessment was done by Novice One based on the specific form and guideline given by the Education Department, Kedah. A panel of assessors discusses the teacher performance, and student marks in examinations is the most important criterion to fulfil. Besides that, the school administrators' recommendations are also considered. This process explained the decision step in CPM for Novice One. Overall, it is clear that Novice One realised and followed all the six steps in CPM. The only issue arises is whether he/she did not follow the proper CPM steps which have been discussed before. 
Appendix 1B: Expert One Cognitive Maps on CPM in Performance Appraisal Decision
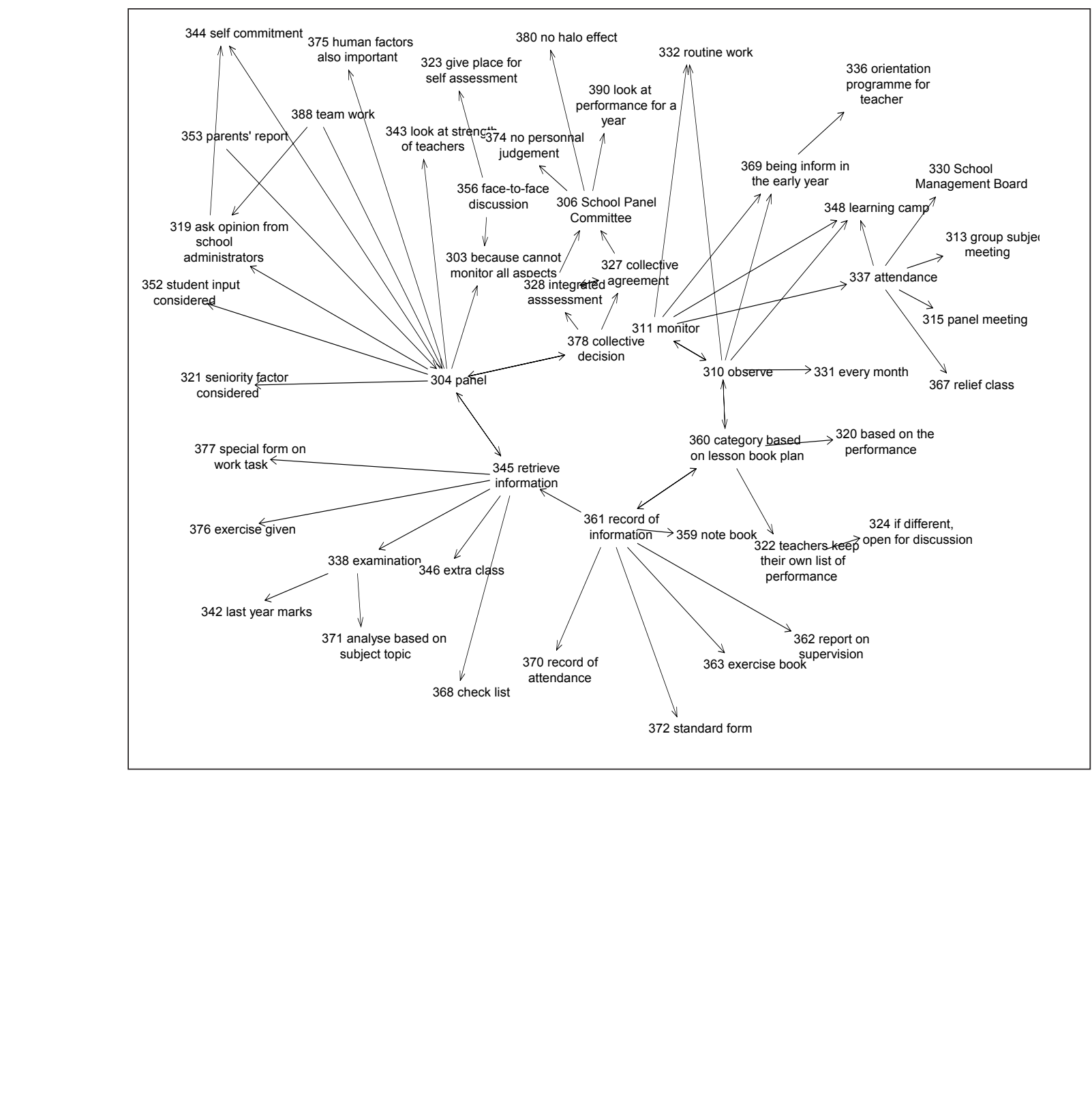